\title{
The Audiometric Findings among Curitiba and Metropolitan Area Students
}

\author{
Regina Klas ${ }^{1}$ Adriana Lacerda ${ }^{1}$ \\ ${ }^{1}$ MSc, PhD, Communication Disorder, Universidade Tuiuti do Paraná, \\ Curitiba, Paraná, Brazil \\ Address for correspondence Regina Klas, MSc, PhD, Communication \\ Disorder, Universidade Tuiuti do Paraná, Rua sydnei lima santos 238, \\ Curitiba, Paraná 82010-330, Brazil (e-mail: regklas@gmail.com).
} Int Arch Otorhinolaryngol 2014;18:165-171.

\begin{abstract}
Keywords

- hearing

- hearing loss

- public health

Introduction Hearing loss can compromise the language, learning process, and socialization of students.

Objective Study the audiometric findings among Curitiba and Metropolitan Area students.

Methods Analysis of data collected at the hearing health service of Paraná State special education and inclusion department.

Results The sample consisted of 646 students, children and teenagers of both genders (38.2\% female and $61.8 \%$ male), with average age of 8.12 years (range 2 to 15 ); all were students of public or private schools of Curitiba and Metropolitan Area. The justifications to refer the students to audiometric evaluation were: otolaryngologists diagnosis (73.1\%), school difficulties (39.6\%), and midlevel hearing problems (32\%). Audiometric results showed that $29.5 \%$ of the students had hearing loss. Conductive hearing losses showed the greatest occurrence among preschool students (right ear 38.6\%, left ear 39.8\%). The predominant hearing loss degree was mild (RE 20.5\%, LE 19.3\%) to slight (RE 17\%, LE 19.3\%), as was the horizontal configuration (RE 81.5\%, LE 78.4\%). A significant relationship $(p=0.0000)$ between hearing loss and poor school performance was noted.

Conclusion Considering the available data, especially the high number of findings of conductive losses, it is necessary to highlight prevention and diagnosis of early hearing alteration. Nevertheless, Brazil, as an emerging country, has been pursuing improvement in health and life quality of all citizens.
\end{abstract}

\section{Introduction}

Human hearing allows for interaction between human beings and the environment in which they live. Hearing deprivation interferes with the overall developmental process and, consequently, education, emotional, organic, social, and, above all, language development. ${ }^{1,2}$

Due to the limitations imposed by auditory deprivation with serious implications for the child, family, and society and because of its high incidence and prevalence, hearing loss has been the subject of concern. Studies have been performed searching for interventions that can mitigate its deleterious effects on the social, emotional, cognitive, and organic development of the individual. ${ }^{3,4}$

Service for the pediatric population is a challenge in addressing primary health care, with middle ear disease used as a major diagnosis in children. The high prevalence of middle ear disease and its implications caused the World Health Organization to consider the skills for the diagnosis and treatment of otitis media in childhood as a priority to be developed by professionals of primary health. ${ }^{5}$ Studies show that otitis media is the most common hearing disorder in children., ${ }^{4,6-10}$ received

September 23, 2013

accepted

December 4, 2013
DOI http://dx.doi.org/

10.1055/s-0034-1366975. ISSN 1809-9777.
Copyright (c) 2014 by Thieme Publicações License terms Ltda, Rio de Janeiro, Brazil 
So hearing loss in childhood reveals the necessity of public health surveillance due to its high prevalence and mainly because it damages learning and socialization, making it essential to identify early hearing loss in school-aged children. ${ }^{3,4,11}$ Thus, some studies show concern about the occurrence of hearing loss in school. ${ }^{2-4,7,9,10,12-14}$

In light of this reality, the study was set up to analyze the audiometric profile of schoolchildren in Curitiba and the metropolitan area, with a view to promoting improvements in hearing health education and public policy.

\section{Methods}

This is a cross-sectional quantitative study; survey data were analyzed from January 2009 to December 2010. To select the sample, we used the database of the Hearing Assessment Service (HAS), a public institution, which serves children for auditory evaluations in public and private schools. We used the audiometry results for children from preschool and elementary school. We excluded data from children under 2 years of age, because it was not possible to obtain pure tone thresholds via conventional audiometry, making other audiological resources necessary. Therefore, the sample consisted of 646 students at preschool and elementary school levels.

In the audiometric assessment, a full medical history was taken, and the external auditory canal was viewed with a HEINE otoscope (Heine Optotechnik; Herrsching, Germany). Pure tone audiometry was performed with an Interacoustic AC 30 and AC 40 Audiometer (Interacoustics AS; Assens, Denmark). The equipment was calibrated according to ISO 8253-1.

We considered the type of hearing loss, degree of hearing loss, and audiometric configuration, as recommended by the Federal Speech-Language Pathology Council for audiological reports. ${ }^{15}$ The results of audiometry were analyzed by the variables of educational level, gender, reason for visit, type of hearing loss, degree of hearing loss, and audiometric curve.
Audiometric data and characteristics of the population regarding the sample were analyzed by Student $t$ test at a significance level of $0.05(5 \%)$.

Consent for use of the database had a safeguarding of data samples using page orders from the Superintendent of the State Department of Education and the Director of CRAID by the State Department of Health.

The study was approved by the Charter of the Coordinating Committee for Ethics in Human Research under registration No. $1038-11$.

\section{Results}

The sample consisted of $38.2 \%$ females in preschool (5.1\%) and in elementary school (33.1\%). As for males, $8.5 \%$ were in preschool and $53.3 \%$ in elementary school. The average age was 8.12 (range 2 to 15 ), from municipal (77.7\%), state (18\%), and private (4.3\%) schools in the city of Curitiba and its metropolitan area.

- Table 1 shows the reasons that students were referred for audiometry by the HAS, distributed according to level of education. This table also shows that the referral to the HAS was based on referrals from otorhinolaryngologists.

- Table 2 shows the type of loss according to the level of education of the schoolchildren, stressing that the audiometric findings related to conductive hearing loss had the highest occurrence in preschool.

- Table 3 illustrates the degree of hearing loss of students by level of education; we observed mild or minimal to mild loss with higher occurrence in elementary school.

- Table 4 shows the distribution of students according to the audiometric curve of students by level of education. There was a predominance of horizontal curves in the audiometric results of the schoolchildren.

The comparison between the average hearing thresholds according to the level of education is presented in - Table 5 .

Table 1 Distribution of students by educational level per referral reason $(n=646)$

\begin{tabular}{|l|l|l|l|l|}
\hline \multirow{2}{*}{ Reason for referral } & \multicolumn{4}{c|}{ Educational level } \\
\cline { 2 - 5 } & \multicolumn{2}{|c|}{ Preschool } & \multicolumn{2}{c|}{ Elementary } \\
\cline { 2 - 5 } & $n$ & $\%$ & $n$ & $\%$ \\
\hline ENT diagnosis & 35 & 39.8 & 186 & 33.3 \\
\hline Difficulty in school & 4 & 4.5 & 196 & 35.1 \\
\hline ME problems (otalgia, otitis, ear discharge, ventilation tube) & 19 & 21.6 & 58 & 10.4 \\
\hline Prenatal surgery (tonsils and/or adenoids) & 13 & 14.8 & 33 & 5.9 \\
\hline Speech deficiency & 12 & 13.6 & 30 & 5.4 \\
\hline Mouth breathing & 2 & 2.3 & 4 & 0.7 \\
\hline Inattention & 1 & 1.1 & 14 & 2.5 \\
\hline Meningitis & 1 & 1.1 & 8 & 1.4 \\
\hline Other & 1 & 1.1 & 20 & 3.6 \\
\hline No response & - & 0.0 & 9 & 1.6 \\
\hline Total & 88 & 100 & 558 & 100 \\
\hline
\end{tabular}

Abbreviations: ENT, otorhinolaryngologic; ME, middle ear. 
Table 2 Distribution of sample by type of hearing loss in accordance with level of education $(n=646)$

\begin{tabular}{|l|l|l|l|l|}
\hline \multirow{2}{*}{ Type of loss } & \multicolumn{3}{|c|}{ Educational level } \\
\cline { 2 - 5 } & \multicolumn{1}{|c|}{ Preschool } & \multicolumn{3}{c|}{ Elementary } \\
\cline { 2 - 5 } & Right ear & Left ear & Right ear & Left ear \\
\hline Normal & $51(58.0 \%)$ & $50(56.8 \%)$ & $460(82.4 \%)$ & $472(84.6 \%)$ \\
\hline Conductive & $34(38.6 \%)$ & $35(39.8 \%)$ & $69(12.4 \%)$ & $57(10.2 \%)$ \\
\hline Mixed & 0 & 0 & $10(1.8 \%)$ & $10(1.8 \%)$ \\
\hline Sensorineural & $3(3.4 \%)$ & $3(3.4 \%)$ & $19(3.4 \%)$ & $19(3.4 \%)$ \\
\hline Total & $88(100 \%)$ & $88(100 \%)$ & $558(100 \%)$ & $558(100 \%)$ \\
\hline
\end{tabular}

Note: A significant difference was found in the proportions of normal hearing between preschool and elementary levels in both ears $(p<0.0001)$ and also conductive hearing loss in both ears $(p<0.0001)$. Cases of normal hearing were significantly higher in elementary school, and the proportion of conductive hearing loss is higher in preschool.

Table 3 Distribution of students per degree of hearing loss according to the level of education $(n=646)$

\begin{tabular}{|l|l|l|l|l|l|l|l|l|}
\hline \multirow{3}{*}{ Degree of hearing loss } & \multicolumn{9}{|c|}{ Educational level } \\
\cline { 2 - 12 } & \multicolumn{4}{|c|}{ Preschool } & \multicolumn{4}{c|}{ Elementary } \\
\cline { 2 - 12 } & \multicolumn{2}{|c|}{ Right ear } & \multicolumn{2}{c|}{ Left ear } & \multicolumn{2}{c|}{ Right ear } & \multicolumn{2}{c|}{ Left ear } \\
\cline { 2 - 12 } & $n$ & $\%$ & $n$ & $\%$ & $n$ & $\%$ & $n$ & $\%$ \\
\hline Slight & 18 & 20.5 & 17 & 19.3 & 17 & 3.0 & 14 & 2.5 \\
\hline Mild & 15 & 17.0 & 17 & 19.3 & 52 & 9.3 & 46 & 8.2 \\
\hline Moderate & 2 & 2.3 & 3 & 3.4 & 11 & 2.0 & 10 & 1.8 \\
\hline Moderately severe & 1 & 1.1 & - & 0.0 & 5 & 0.9 & 4 & 0.7 \\
\hline Severe & 1 & 1.1 & 1 & 1.1 & 5 & 0.9 & 1 & 0.2 \\
\hline Profound & - & 0.0 & - & 0.0 & 7 & 1.3 & 10 & 1.8 \\
\hline Normal & 51 & 58.0 & 50 & 56.8 & 461 & 82.6 & 473 & 84.8 \\
\hline Total & 88 & 100 & 88 & 100 & 558 & 100 & 558 & 100 \\
\hline
\end{tabular}

Table 4 Distribution of students by audiometric curve configuration, according to the level of education $(n=646)$

\begin{tabular}{|l|l|l|l|l|l|l|l|l|}
\hline \multirow{3}{*}{ Audiometric curve configuration } & \multicolumn{9}{|c|}{ Educational level } \\
\cline { 2 - 10 } & \multicolumn{4}{|c|}{ Preschool } & \multicolumn{5}{c|}{ Elementary } \\
\cline { 2 - 10 } & \multicolumn{2}{|c|}{ Right ear } & \multicolumn{2}{|c|}{ Left ear } & \multicolumn{2}{c|}{ Right ear } & \multicolumn{2}{c|}{ Left ear } \\
\cline { 2 - 10 } & $n$ & $\%$ & $n$ & $\%$ & $n$ & $\%$ & $n$ & $\%$ \\
\hline Flat & 68 & 77.3 & 66 & 75.0 & 479 & 85.8 & 457 & 81.9 \\
\hline Rising & 9 & 10.2 & 5 & 5.7 & 14 & 2.5 & 10 & 1.8 \\
\hline Sloping, lightly & 5 & 5.7 & 5 & 5.7 & 25 & 4.5 & 42 & 7.5 \\
\hline Sloping, steeply & 1 & 1.1 & 1 & 1.1 & 13 & 2.3 & 18 & 3.2 \\
\hline Notched & 2 & 2.3 & 3 & 3.4 & 14 & 2.5 & 17 & 3.0 \\
\hline Tent-shaped & 2 & 2.3 & 8 & 9.1 & 8 & 1.4 & 9 & 1.6 \\
\hline Sloping, ski jump & - & 0.0 & - & 0.0 & 3 & 0.5 & 2 & 0.4 \\
\hline u-shaped & 1 & 1.1 & - & 0.0 & 2 & 0.4 & 2 & 0.4 \\
\hline Sloping & - & 0.0 & - & 0.0 & - & 0.0 & 1 & 0.2 \\
\hline Total & 88 & 100 & 88 & 100 & 558 & 100 & 558 & 100 \\
\hline
\end{tabular}


Table 5 Comparison between averages for pure tone audiometric thresholds based on level of education $(n=646)$

\begin{tabular}{|l|l|l|l|l|l|}
\hline \multirow{2}{*}{ Ear and frequency (Hz) } & \multicolumn{4}{|c|}{ Educational level } & \multirow{2}{*}{} \\
\cline { 2 - 5 } & \multicolumn{2}{|c|}{ Preschool } & \multicolumn{2}{c|}{} \\
\cline { 2 - 5 } & Average & $\mathbf{n}_{1}$ & Average & $\mathbf{n}_{2}$ & \\
\hline RE 500 & 20.6 & 88 & 558 & 16.7 & $0.0229^{\mathrm{a}}$ \\
\hline RE 1,000 & 16.6 & 88 & 558 & 13.0 & 0.0602 \\
\hline RE 2,000 & 12.2 & 88 & 558 & 9.8 & 0.2139 \\
\hline RE 3,000 & 11.5 & 88 & 558 & 9.4 & 0.2777 \\
\hline RE 4,000 & 14.6 & 88 & 558 & 10.8 & 0.0715 \\
\hline RE 6,000 & 20.6 & 43 & 538 & 15.5 & 0.0773 \\
\hline RE 8,000 & 19.5 & 43 & 535 & 15.1 & 0.1074 \\
\hline LE 500 & 20.3 & 88 & 558 & 16.0 & $0.0147^{\mathrm{a}}$ \\
\hline LE 1,000 & 16.0 & 88 & 558 & 11.7 & $0.0280^{\mathrm{a}}$ \\
\hline LE 2,000 & 12.5 & 88 & 558 & 9.5 & 0.1462 \\
\hline LE 3,000 & 11.6 & 88 & 558 & 9.2 & 0.2336 \\
\hline LE 4,000 & 14.7 & 88 & 558 & 10.3 & $0.0393^{\mathrm{a}}$ \\
\hline LE 6,000 & 19.1 & 43 & 538 & 16.4 & 0.3749 \\
\hline LE 8,000 & 19.3 & 43 & 536 & 15.7 & 0.2195 \\
\hline
\end{tabular}

Abbreviations: LE, left ear; RE, right ear.

${ }^{a}$ Note: Student $t$ test found significant differences for the following cases: RE at $500 \mathrm{~Hz}$ and LE at 500, 1,000, and 4,000 Hz.

Significant differences were found when comparing the average of the hearing thresholds at frequencies of $500 \mathrm{~Hz}$ in the right ear and 500,1,000, and 4,000 Hz in the left ear. Cases of normal hearing were significantly higher in elementary school, and conductive hearing loss was more common in preschool.

-Fig. 1 shows the correlation between the results of audiometry (normal and with hearing loss) and poor academic performance (preschool and high school). Chi-square test, at a significance level of $0.05(5 \%)$, showed a significant relationship $(p<0.0001)$ between audiometric thresholds

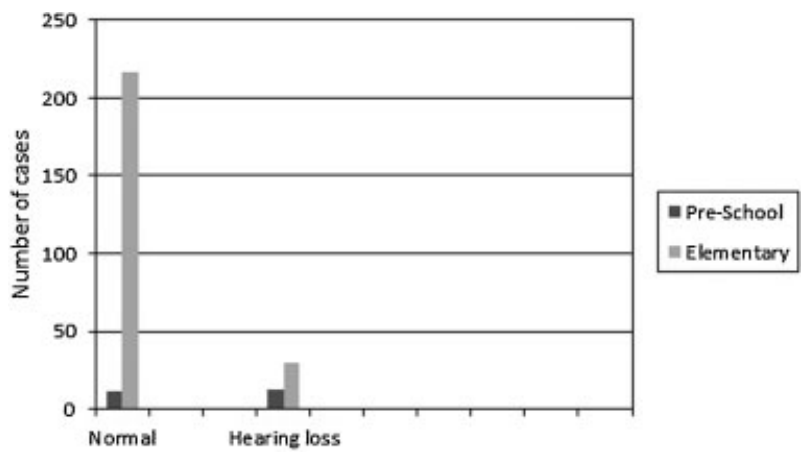

Fig. 1 Correlation between the results of audiometry (normal and with hearing loss) and poor academic performance (preschool and high school). Chi-square test showed a significant relationship $(p<0.0001)$ between audiometric thresholds and poor school performance. The proportion of cases with hearing loss is significantly higher among preschoolers with poor performance. and poor school performance. The proportion of cases with hearing loss was significantly higher among preschoolers with poor performance.

\section{Discussion}

This study investigates hearing in schoolchildren in Curitiba and its metropolitan area. The results were obtained by means of audiometric findings aimed at collecting data for improvement in promoting hearing health education and public policy. There were more male students than female students. These results are similar to research by some authors. $^{3,11,16}$

Referrals for audiometry occur for mostly diagnostic purposes ( - Table 1 ). Monitoring of middle ear problems and presurgical evaluations have also been reported. These data reflect the fact that state and local public policies are aimed at diagnosis and not prevention. However, to prevent possible health deficiencies and problems in infancy, the City Department of Education launched a program in 2005 called "Warning Signs: Prevention in Early Childhood Education in Curitiba," with the aim of developing in educators, teachers, and families an awareness of the importance of early intervention as well as identification of risk factors, monitoring, and more appropriate routing. ${ }^{16}$

In the same setting, the Curitiba City Department of Health, in Law 11.393/2005-P16, provides for mandatory periodic audiological tests in public health care clinics, child care facilities, and schools; however, this initiative has not yet been implemented. The priority for medical and/or 
therapeutic treatment of children is focused on signs of developmental delays in children, with assistance in intervention, and the prevention of future disability or chronic health problems.

Another justification for referrals that was difficulty in school (-Table 1). Once learning problems are linked to hearing loss, the audiologist's participation in the school would be essential to educational success. ${ }^{1}$ The study shows that a lack of knowledge on the part of teachers regarding hearing loss, insecurity, and feelings of unpreparedness contribute to late diagnosis.

Thus, the Program for Hearing Health Promotion and Prevention in Schoolchildren is an important strategy in raising the topic of hearing loss, examining the school environment, facilitating early diagnosis, and promoting educational activities to avoid the impact of hearing loss in the areas of language, learning, and socialization. ${ }^{17-22}$

The findings are compatible with a study that determined the characteristics of chronic otitis media, raising the possibility of classification of conductive hearing loss (- Table 2 ). ${ }^{4}$ Another study concluded that the incidence of mild hearing loss, which is significant in the school band, is the most frequent factor. ${ }^{7}$ The authors studied 150 children from a Center for the Study of Education and Health, and 48 of them had conductive hearing loss. ${ }^{13}$

Some authors have demonstrated, in a study conducted in southeastern Brazil, that the prevalence of chronic otitis media in children of school age is $0.94 \%$ and that $~ 80 \%$ of them have at least one episode of serous otitis media by the age of $8 .{ }^{9}$ Of affected children, $~ 55 \%$ have hearing loss. The fluctuating nature of hearing loss in otitis media leading to an inconsistent sound stimulation of the central auditory nervous system makes perception of speech sounds difficult for the child. Moreover, fluid in the middle ear may cause noise along the cochlea, distorting sound perception.

Research on the prevalence of different types of ear disease in school children of the Kathmandu Valley (5 to 12 years old) demonstrated that chronic suppurative otitis media was present in $85.9 \%$ of the group. ${ }^{8}$ The authors pointed out the need for guidance on health, as well as improvement of socioeconomic status and health facilities in the community, to reduce the prevalence of ear diseases.

Authors in an exploratory study in the city of Goiania that included 121 schoolchildren from first to eighth grade ( 7 to 14 years old) showed that $24 \%$ of audiometry tests showed abnormalities, with higher occurrence of conductive hearing loss in $12 \%$ of the subjects, followed by mild sensorineural hearing loss in $7 \%{ }^{7}$ The authors concluded that conductive hearing loss can impair a student's attention. Therefore, its early diagnosis and treatment are necessary to improve academic performance.

A study on 150 children, 5 to 10 years old, at a Center for the Study of Education and Health in the city of Marilia, Sao Paulo, showed that 93 children had hearing thresholds within normal limits, 36 had bilateral loss, and 21 had unilateral hearing loss; 48 were conductive, 2 were sensorineural, and 7 were mixed. ${ }^{13}$ The authors consider otitis media to be a basic health problem and suggested preventive measures and hearing health behavior actions.

The profile of patients in the Hearing Care Program of the State of Santa Catarina was described in a study. ${ }^{14}$ Analysis of 304 records revealed that the pediatric group (10.2\%) had sensorineural hearing loss from mild to severe levels, and the adult group (89.8\%) had sensorineural hearing loss of moderate to moderately severe levels.

-Table 3 relates the information obtained about the degree of hearing loss and level of education; the indicators equivalent to mild or minimal to mild loss in elementary school are present in higher numbers. This sample shows similarity with the results of some studies. ${ }^{14,23,24}$

According to the level of education, there was a predominance of horizontal curves in the audiometric results of students at both the preschool and elementary school levels (-Table 4). In this context, studies confirmed that the configuration of horizontal, ascending, and irregular curves accounted for $90.5 \%$ of the ears studied, as well as losses with flat audiometric curves. ${ }^{13,25}$

The comparison between average hearing thresholds according to the level of education is presented in - Table 5, and significant differences were found when comparing the average hearing thresholds at specific frequencies. Cases of normal hearing were significantly higher in elementary school, and for conductive loss, the proportion was higher in preschool.

-Fig. 1 shows the impact of hearing loss on academic performance, especially in early childhood education. Studies have shown a close relationship between language problems and/or education and hearing loss, especially those caused by middle ear pathologies and especially when its manifestations occur early in life. In some cases, students are labeled as inattentive or restless, or even as having learning difficulties.

Some authors highlighted that a loss of sound experiences, as a consequence of acquired hearing loss mainly caused by recurrent otitis, influences oral language acquisition and learning because the presence of this condition does not impede the development of language but changes the breakdown of speech, especially in noisy environments, which can also compromise phonological awareness and therefore school performance. ${ }^{26}$

In one study, $80 \%$ of children had at least one episode of CSOM (chronic serous otitis media) by the age of 8 . Of affected children, 55\% had mild hearing loss in the frequencies needed to understand speech. The aim of our study was to associate the relationship of middle ear infections and school performance in 160 children from 6 to 8 years of age. The results indicated impairment in academic performance and language skills of children with recurrent otitis media. Mild hearing loss is enough to impair certain auditory functions. ${ }^{4}$

One study indicated that teachers often lack tools to relate problems in school performance with possible hearing loss. ${ }^{27}$ Moreover, some teachers are unaware of rights and remedies available for the protection and optimization of hearing that children can access. In this sense, the authors recognized the importance of implementation of health promotion programs in the school environment and the need to develop 
projects on the theme of hearing health and hearing disorders in school to promote teacher training. ${ }^{1}$

The data cited in this study emphasize the results and enable the evaluation of the quality of hearing health in schoolchildren, as well as provide epidemiologic research aiming to increase knowledge about the population with hearing loss and support the planning of programs resulting from this action. Therefore, the study will allow managers in education and health to identify the points to be monitored and evaluated for continuous improvement of more comprehensive hearing health care ${ }^{28}$ and to develop an attentive hearing health policy based on public policy and involving prenatal monitoring, the postpartum period, and the growth and development of children. The dimensions of the problem of hearing loss in Curitiba and its metropolitan area should provide for the statewide collection of data and information to update knowledge on hearing.

It is still difficult to make an early diagnosis of hearing loss in school-aged children, despite knowing that the sooner the intervention occurs, the bigger and better the results in the development process will be. ${ }^{29}$

This study had some limitations related to the information contained in the database of the HAS, especially on issues relating to language learning and socialization. Moreover, we had no access to or contact with the school, which could contribute to the knowledge of the learning situation of the participants. Further research should be undertaken to establish the correlation of auditory situations, especially related to student learning. Information related to school performance should be valued in audiological medical history.

It is the desire of all those responsible for health and education to encourage more discussion on health policies with the participation of democratic spaces of social control. At the same time, it is important to delineate alternatives to guarantee social rights and also fight for a health system that is more efficient and inclusive. The present moment is intriguing as new challenges and research are being launched to improve school attendance in Brazil. Thus, the discussions in the annual Public Policy Seminars, Services and Systems, Public Policy Forums, International Audiology Meetings, as well as other events, have been fundamentally important to the development of this area. With the help of community agents and family health strategies or school health programs, as well as the professionals who work in health centers, students with acquired hearing loss or late-onset hearing impairments could be identified early and referred for diagnosis and treatment.

The paradigm of the health care of schoolchildren, as well as quality of life, requires a comprehensive action that goes beyond the determinants of health. Interdisciplinary and intersectoral action in an integrated and synchronized manner that is planned by educational and health administrators is necessary, enabling early diagnoses and appropriate interventions within the context of the community in which they are operating. It is therefore necessary to examine social, environmental, and lifestyle factors to reduce the processes that can result in risk and to favor those that are protective and healthy. Health education with a holistic approach meets the needs of the student at each stage of development. In this way, we can take health as a social construct, addressing the interrelation of health problems with their determinants within each context. ${ }^{30}$

\section{Conclusion}

Considering the data obtained in this study, with a sample of 646 students of both sexes with ages ranging from 2 to 15 years old, it was concluded that:

- Of the students, $70.4 \%$ had normal hearing.

- Most loss ranged from mild or minimal to mild.

- The audiometric curve was most frequently horizontal at all levels of education.

- Conductive hearing loss had a higher incidence in preschool.

- There is a significant relationship $(p<0.0001)$ between hearing loss and low school performance.

The results presented in this study indicate the need for implementation of hearing conservation programs with an emphasis on hearing health care and the overall health of the schoolchildren.

\section{References}

1 Silva LPA, Queiros F, Lima I. Fatores etiológicos da deficiência auditiva em crianças e adolescentes de um centro de referência APADA em Salvador-BA. Rev Bras Otorinolaringol 2006;72(1): 33-36

2 Collela-Santos MF, Bragatto GR, Martins PMF, Dias AB. Triagem auditiva em escolares de 5 a 10 anos. Revista CEFAC 2009;11(4): 644-653

3 Vasconcelos RM. Avaliação auditiva em escolares da rede pública municipal de São Luis do Maranhão [Dissertação (Mestrado)]. São Luis do Maranhão, Brazil: Universidade Federal do Maranhão; 2006

4 Sitta ÉI, Arakawa AM, Oliveira AN, et al. Triagem audiológica em pré-escolares com histórico de otite média. Salvador, Abr./Jun. Rev Ba Saude Publica 2010;34(2):388-396

5 Martins L, Guimarães RES, Becker HMG, Bredan MB, Medeiros M Camargos P. Baixa prevalência de doenças do ouvido médio em pacientes com fibrose cística. Rio de Janeiro. J Pediatr (Rio J) 2011; 87(1):80-83

6 Lacerda ABM, Ribas A, Siqueira MMP. Triagem Auditiva Escolar: uma justificativa para sua realização. J Bras Fonoaudiol 2002; 3(12):229-232

7 Araujo SA, et al. Avaliação auditiva em escolares. São Paulo. Rev Bras Otorinolaringol 2002;68:263-266

8 Prakash A, et al. Padrão de Doenças Otológicas em Crianças em Idade Escolar do Vale do Kathmandu. Int Arch Otorhinolaryngol 2008;12(4):502-505

9 Balbani APS, Montovani JC. Impacto das otites médias na aquisição da linguagem em crianças. J Pediatr (Rio J) 2003;79(5):391-396

10 Rezende AG, Guedes AP, Lima C, Borrego MC, Gushikem P, Chiari BM. Prevenção da instalação de problemas de linguagem decorrentes de perdas auditivas derivadas dos quadros de otites médias e de repetição. Rev Bras Med Otorrinolaringol 1995; 2(2):90-92

11 Mondelli MFCG, Bevilacqua MC. Estudo da deficiência auditiva das crianças do HRAC-USP, Bauru, SP: subsídios para uma política de intervenção. Sinopse de Pediatria 2002;8(3):51-62 
12 Schirmer CR, Fontoura DR, Nunes ML. Distúrbios da aquisição da linguagem e da aprendizagem. J Pediatr (Rio J) 2004;80(2):95-103

13 Guida HL, Diniz TH. Perfil Audiológico em Crianças de 5 a 10 Anos de Idade. Int Arch Otorhinolaryngol 2008;12(2):224-229

14 Dimatos OC, Ikino CMY, Philippi PA, Dimatos SC, Birck MS, Freitas P. Perfil dos pacientes do Programa de Saúde Auditiva do Estado de Santa Catarina atendidos no HU-UFSC. Int Arch Otorhinolaryngol 2011;15(1):59-66

15 Conselho Federal de Fonoaudiologia. Orientações dos Conselhos de Fonoaudiologia para o Laudo Audiológico. Laudo audiológico-Audiometria Tonal, Logoaudiometria e Medidas de Imitância Acústica. Brasília: Conselhos Federal e Regionais de Fonoaudiologia; 2009

16 Curitiba. Camara Municipal de Curitiba. Lei 11.393/2005, de 25 de abril de 2005. Dispõe sobre a obrigatoriedade de realização de testes audiológicos periódicos nos postos de saúde, creches e unidades escolares do município e dá outras providências. Curitiba Brazil: Diário Oficial da Prefeitura Municipal de Curitiba; 2005. Available at: www.cidadedoconhecimento.org.br/cidadedoconhecimento/index.php?portal $=530 \&$ cod_proje $=1603$. Accessed December 18, 2011

17 Serra MRB, Biassoni EC, Hinalaf M, et al. Program for the conservation and promotion of hearing among adolescents. Am J Audiol 2007;16(2):S158-S164

18 Martin WH. Dangerous decibels: partnership for preventing noise-induced hearing loss and tinnitus in children. Semin Hear 2008;29(1):102-110

19 Lacerda ABM. Tratado de Audiologia. In: Bevilacqua MC, Martinez MAN, Balen SA, et al, eds. Audição no contexto da educação: práticas voltadas à promoção e prevenção. São Paulo: Brazil Santos; 2011. Seção VIII: Audiologia Educacional 33:549-569

20 Melo, MEOP. Hein? Hã? Quê? Compreendendo as relações entre aprendizado e alterações audiológicas em escolares. [Dissertação (Mestrado)]. Fortaleza, Brazil: Universidade de Fortaleza, Centro de Ciências da Saúde; 2003
21 Ramos BD. Importância da audição no desenvolvimento da linguagem. Otologia e Audiologia em Pediatria. In: Caldas N, Caldas Neto S, Sih T, eds. Otologia e audiologia em pediatria: Importância da audição no desenvolvimento da linguagem. Otologia e Audiologia em Pediatria. Rio de Janeiro Brazil: Revinter; 1999:168-171

22 Godoy MA. A disfunção tubária e otites-suas implicações no desenvolvimento da linguagem. Available at: http://www.fonoaudiologia.com/trabalhos/monografias/monografia-004/monografia-004-pg05.htm. Accessed June 26, 2011

23 Penido NO, Ramos HVL, Barros FA, Cruz OLM, Toledo RN. Fatores clínicos, etiológicos e evolutivos da audição na surdez súbita. Rev Bras Otorrinolaringol (Engl Ed) 2005;71(5):633-638

24 Brasil, Ministério da Saúde. Política Nacional de Atenção à Saúde Auditiva. Brasília. Portaria no. 2073/GM de 28 de setembro de 2004 Institui a Política Nacional de Atenção auditiva. Brasília Brazil: Diário Oficial da República Federativa do Brasil; 2004

25 Folmer RL. Hearing loss prevention practices should be taught in schools. Semin Hear 2008;29(1):67-80

26 Luz DM, Costa-Ferreira MID. Identificação dos fatores de risco para o transtorno do processamento auditivo (Central) em Pré-Escolares. Rev CEFAC 2011;13(4):657

27 Trenche MCB, Balieiro CR. Tratado de Audiologia. In: Bevilacqua MC, Martinez MAN, Balen SA, et al, eds. Assessoria Fonoaudiológica à Escola. São Paulo Brazil: Editora Santos; 2011:745-757

28 Penteado RZ. Escolas Promotoras da Saúde-implicações para a ação fonoaudiológica. Rev Soc Bras Fonoaudiol 2002;2(1):28-37

29 Penteado RZ, Servilha EAM. Fonoaudiologia em saúde pública coletiva: compreendendo prevenção e o paradigma da promoção da saúde. Distúrbios Comunicação 2004;16(1):107-116

30 Brasil. Ministério da Saúde. Secretaria de Vigilância em Saúde. Programa Nacional de DST e AIDS. Diretrizes para implantação do Projeto Saúde e Prevenção nas Escolas. Secretaria de Vigilância em Saúde. Série A-Normas e Manuais Técnicos. Brasília, Brazil: Ministério da Saúde; 2006 